\title{
Trypanosoma cruzi: parasite persistence in tissues in chronic chagasic Brazilian patients
}

\author{
Gláucia E Barbosa Marcon'1, Dulcinéia Martins de Albuquerque', Angelica Martins Batista1, \\ Paula Durante Andrade', Eros A Almeida', Maria Elena Guariento', \\ Maria AB Teixeira ${ }^{2}$, Sandra C Botelho Costa ${ }^{1 /+}$
}

\begin{abstract}
1'Departamento de Clínica Médica, Faculdade de Ciências Médicas, Universidade Estadual de Campinas, Campinas, SP, Brasil ${ }^{2}$ Grupo de Estudo em Correlação Anátomo-Clínica, Faculdade de Medicina, Pontifícia Universidade Católica de Campinas, Campinas, SP, Brasil
\end{abstract}

Chagas disease in the chronic phase may develop into cardiac and/or digestive forms. The pathogenesis of the disease is not yet clear and studies have been carried out to elucidate the role of parasite persistence in affected organs. The aim of this study was to detect and quantify Trypanosoma cruzi in paraffin-embedded tissue samples from chronic patients using NPCR (nested polymerase chain reaction) and QPCR (quantitative polymerase chain reaction) methods. These results were correlated to anatomopathological alterations in the heart and gastrointestinal tract (GIT). Of the 23 patients studied, 18 presented the cardiac form and five presented the cardiodigestive form of Chagas disease. DNA samples were randomly isolated from formalin-fixed paraffin-embedded sections of heart and GIT tissue of 23 necropsies and were analyzed through NPCR amplification. T. cruzi DNA was detected by NPCR in 48/56 (85.7\%) heart and 35/42 (83.3\%) GIT samples from patients with the cardiac form. For patients with the cardiodigestive form, NPCR was positive in 12/14 (85.7\%) heart and in 14/14 (100\%) GIT samples. QPCR, with an efficiency of $97.6 \%$, was performed in 13 samples (11 from cardiac and 2 from cardiodigestive form) identified previously as positive by NPCR. The number of T. cruzi copies was compared to heart weight and no statistical significance was observed. Additionally, we compared the number of copies in different tissues (both heart and GIT) in six samples from the cardiac form and two samples from the cardiodigestive form. The parasite load observed was proportionally higher in heart tissues from patients with the cardiac form. These results show that the presence of the parasite in tissues is essential to Chagas disease pathogenesis.

Key words: Trypanosoma cruzi - real-time PCR - nested PCR - Chagas disease

The chagasic infection caused by the Trypanosoma cruzi protozoan may have a different evolution based on the circumstance and situation. The parasite-host interaction is dynamic and results from several factors related to the trypanosome (strain, virulence and inoculation), the human host (age, gender and genetic profile) and the environment. T. cruzi infection affects between 12-14 million people and approximately $25 \%$ of the Latin American population is at risk of contracting Chagas disease (WHO 2002).

It is believed that there are two phases of the disease: the acute phase and the chronic phase. The acute phase is characterized by parasites found throughout the body, replicating within macrophages and a variety of other host cells, especially cardiac muscle cells. It is histopathologically characterized by inflammatory infiltration and tissue necrosis (Soares \& Ribeiro dos Santos 1999). Following an acute infection, the chronic phase is characterized by a variable clinical course ranging from absence of symptoms to severe cardiac and/or gastrointestinal involvement (Macedo et al. 2002).

Financial support: FAPESP, CAPES

+ Corresponding author: costa@fcm.unicamp.br

Received 22 July 2010

Accepted 24 November 2010
According to Köberle (1968), the number of parasites decreases from the acute to the chronic phase, both in the blood and in tissues. The period when no clinical symptoms or significant histopathological lesions are found is called the indeterminate form and can last up to 20 years. The typical chronic form of Chagas disease affects the heart in approximately $25 \%$ of the cases. Variable degrees of cardiac hypertrophy and dilatation are found with or without apical aneurysm. The other clinical form consists of dilatation of digestive organs, such as the oesophagus and the colon, as a consequence of neuronal destruction of the gastrointestinal tract (GIT) (Köberle et al. 1983).

The presence of $T$. cruzi close to the disease sites strengthens the hypothesis of parasite persistence in infected tissues, which is based on experimental results obtained through molecular biology techniques and decreased parasite load following specific treatments (Tarleton 2001). In 1993, Jones et al. (1993) detected $T$. cruzi DNA in the heart of autopsied patients by hybridized polymerase chain reaction (PCR), indicating that the persistence of parasite DNA is crucial to the disease pathogenesis and that the inflammatory process is associated with the presence of T. cruzi DNA in infected tissues (Vago et al. 1996).

Adad et al. (1991) reported the finding of chronic inflammatory processes in the oesophagus of asymptomatic chronic chagasic patients and in those presenting megaoesophagus. These findings were confirmed 
by PCR, which amplified T. cruzi DNA both in the oesophagus of patients (Lages-Silva et al. 2001, Elias et al. 2003, Vago et al. 2003) and in infected murine cardiac tissue (Lane et al. 2003).

The PCR quantification method is based on the use of a fluorescent probe $\left(\mathrm{TaqMan}^{\circledR}\right)$ or fluorescent molecules $\left(\mathrm{SYBR}^{\circledR}\right.$ green). This technique consists of realtime monitoring of the quantity of DNA being assessed as numerical values or the number of copies of DNA units. Recently, Duffy et al. (2009) used quantitative PCR (QPCR) to evaluate the parasitic load in children with Chagas disease, in patients under specific treatment and in cases of heart transplantation.

Real-time T. cruzi PCR quantification was described by Cummings and Tarleton in 2003. The examination of infected experimental models revealed sensitive and accurate quantification of parasites in host tissues, with kinetoplastDNA and satellite DNA target fragments, both repetitive regions and in a great number of copies in the T. cruzi genome. It was shown that the detected DNA is derived from the persistence of the parasite in the affected tissues and not from DNA persistence over long periods of time. Piron et al. (2007) used nested PCR (NPCR) and real-time techniques to detect and quantify $T$. cruzi in blood samples of chagasic patients, obtaining a similar positivity rate to results obtained by Marcon et al. (2002). The real-time PCR technique was also employed to detect $T$. cruzi in the amniotic fluid of mothers with Chagas disease (Virreira et al. 2006) and to subtype T. cruzi I and II in infected tissues by means of the difference in primer annealing temperatures. The real-time PCR strategy demonstrated that $T$. cruzi II is the causative agent of the tissue lesions of Chagas disease (Freitas et al. 2005).

Higuchi et al. (2003) emphasized a significant association between the presence of $T$. cruzi antigens in the heart and severe or moderate inflammation, which results from a close interaction between the host and the parasite, causing different clinical cardiac lesions.

The aim of this study was to detect and quantify $T$. cruzi DNA in tissues of chronic chagasic patients using NPCR and real-time PCR methods, respectively.

\section{PATIENTS, MATERIALS AND METHODS}

Patients and samples - The study was approved by the Research Ethics Committee of the Faculty of Medical Sciences, State University of Campinas. DNA samples isolated from paraffin-embedded tissue sections of 23 necropsied individuals with positive serologic and/ or pathological tests for Chagas disease were analyzed through NPCR amplification. Out of 23 patients, 18 presented the cardiac form and five presented the cardiodigestive form of Chagas disease. NPCR was performed in 70 heart tissue samples randomly extracted from sinus node, atrium-ventricular region and cardiac septum. We also analyzed 56 samples from GIT (esophagus, colon and large intestine) (Table I).

The tissues were collected during necropsies conducted between 1986-2005 at the Teaching Hospital of the Catholic University of Campinas, which supplied the epidemiologic and pathological data on the studied cases. In addition to the 126 samples, DNA was isolated from 10 paraffin-embedded heart and GIT sections as negative controls because the patients presented negative epidemiology for Chagas disease. To verify the DNA quality and the absence of inhibitors, the human $\beta$-globin gene was amplified by NPCR (Saiki et al. 1985) in each sample.

For quantitative assays, only 13 positive NPCR DNA samples presented a minimum concentration of DNA to be used in real-time PCR as the standardized concentration for the reaction was $2 \mathrm{ng} / \mu \mathrm{L}$. Out of 13 samples, 11 presented cardiac involvement (C1-C11) and two (CD1 and CD2) presented the cardiodigestive form defined by serological and anatomopathological evidence.

The number of $T$. cruzi DNA copies determined by real-time PCR was used to establish a relationship with heart weight in 13 cases. We also compared the number of copies found in heart and GIT in 8/13 cases of the cardiac form (C1-C6) and cardiodigestive form (CD1 and CD2). Quantification in GIT tissues of C7-C11 and CD3-CD5 was not possible due to the low DNA concentrations.

DNA extraction - For DNA extraction, the samples from paraffin-embedded blocks were sectioned by a microtome 12-15 times at a density of $5 \mu \mathrm{m}$. A disposable blade was used for each block, avoiding any possible contamination. The sections were deparaffinized with heated xylol, hydrated (by means of successive 95\% and $75 \%$ absolute ethanol baths and distilled water) and digested with proteinase $\mathrm{K}(20 \mu \mathrm{g} / \mu \mathrm{L})$ for $72 \mathrm{~h}$ at $60^{\circ} \mathrm{C}$. After digestion, the DNA was isolated with the Qiagen DNeasy Tissue Kit - Uniscience according to the manufacturer's protocol with a final elution volume of $50 \mu \mathrm{L}$.

NPCR - The NPCR was performed as previously described by our group (Marcon et al. 2002) with some modifications. The first reaction was performed with $2 \mu \mathrm{L}$ of the DNA sample, $50 \mathrm{mM}$ of potassium chloride, $10 \mathrm{mM}$ of Tris- $\mathrm{HCl}$ ( $\mathrm{pH}$ 8.4), $2.5 \mathrm{mM}$ magnesium chloride, $2.0 \mathrm{mM}$ of each oligonucleotide (TCZ1 and TCZ2 - first reaction; TCZ3 and TCZ4 - second reaction) described in Table II, deoxyribonucleic mixture $(1 \mathrm{mM})$ - dNTPs (dATP, dGTP, dCTP; dTTP) and $2.0 \mathrm{U}$ of Taq DNA polymerase (Invitrogen) in a final volume of $30 \mu \mathrm{L}$. For the second reaction, the $\mathrm{MgCl}_{2}$ concentration was modified to $2.8 \mathrm{mM}$ and a sample of the PCR product $(0.5-1.0 \mu \mathrm{L})$ was re-amplified with the TCZ3 and TCZ4 oligonucleotides, which resulted in a fragment of 149 base pairs (bp) for positive samples.

The amplification runs were performed with an automatic MJ Research thermocycler. Both reactions were preceded by initial denaturation at $94^{\circ} \mathrm{C}$ for $5 \mathrm{~min}$ and a final extension at $72^{\circ} \mathrm{C}$ for $7 \mathrm{~min}$. In the first five steps, the annealing temperature was at $60^{\circ} \mathrm{C}$ and $65^{\circ} \mathrm{C}$ in the following 25 steps. The amplified fragment of $149 \mathrm{bp}$ was separated by electrophoresis on a $2 \%$ agarose gel stained with ethidium bromide and visualized by ultraviolet transillumination.

Real-time PCR assay - To perform the absolute quantification, standard samples with known amounts of DNA were obtained through cloning of the internal NPCR fragment from the satellite DNA region of T. cru$z i \mathrm{Y}$ strain (TCZ3 and TCZ4 primers), resulting in the 
TABLE I

Patients' data and nested polymerase chain reaction (NPCR) results in blocks of heart and gastrointestinal tract (GIT)

\begin{tabular}{|c|c|c|c|c|c|}
\hline Necropsy & Serology & Clinical form & Anatomopathological evidences & $\begin{array}{c}\text { Heart } \\
\text { tested blocks/ } \\
\text { positive NPCR }\end{array}$ & $\begin{array}{c}\text { GIT } \\
\text { tested blocks/ } \\
\text { positive NPCR }\end{array}$ \\
\hline $\mathrm{C} 1$ & Positive & Cardiopathy & Heart $=620 \mathrm{~g}$, myocarditis & $2 / 2$ & $1 / 1$ \\
\hline $\mathrm{C} 2$ & ND & Cardiopathy & Heart $=490 \mathrm{~g}$ & $2 / 2$ & $2 / 2$ \\
\hline $\mathrm{C} 3$ & Positive & Cardiopathy & Heart $=440 \mathrm{~g}$ & $2 / 2$ & $2 / 2$ \\
\hline $\mathrm{C} 4$ & Positive & Cardiopathy & Heart $=610 \mathrm{~g}$, rosary bead, epycarditis & $2 / 2$ & $2 / 2$ \\
\hline $\mathrm{C} 5$ & Positive & Cardiopathy & Heart $=990 \mathrm{~g}$, apical aneurysm, amastigotes nest & $6 / 6$ & $2 / 2$ \\
\hline C6 & Positive & Cardiopathy & Heart $=390 \mathrm{~g}$, dilated cardiomyopathy & $2 / 2$ & $2 / 2$ \\
\hline $\mathrm{C} 7$ & Positive & Cardiopathy & Heart $=640 \mathrm{~g}$ & $6 / 6$ & $3 / 1$ \\
\hline $\mathrm{C} 8$ & Positive & Cardiopathy & Heart $=450 \mathrm{~g}$, myocarditis & $2 / 2$ & $2 / 2$ \\
\hline C9 & Positive & Cardiopathy & Heart $=420 \mathrm{~g}$, rosary bead, epycarditis & $2 / 2$ & $2 / 2$ \\
\hline $\mathrm{C} 10$ & Positive & Cardiopathy & Heart $=340 \mathrm{~g}$, apical aneurysm & $7 / 4$ & $3 / 3$ \\
\hline C11 & Negative & Cardiopathy & Heart $=375 \mathrm{~g}$, apical aneurysm & $4 / 2$ & $3 / 1$ \\
\hline $\mathrm{C} 12$ & Negative & Cardiopathy & Heart $=350 \mathrm{~g}$, apical aneurysm, myocarditis & $2 / 2$ & $2 / 2$ \\
\hline $\mathrm{C} 13$ & Negative & Cardiopathy & Heart $=400 \mathrm{~g}$, amastigotes nest & $1 / 1$ & $2 / 2$ \\
\hline $\mathrm{C} 14$ & Positive & Cardiopathy & Hearth $=470 \mathrm{~g}$, apical aneurysm & $2 / 1$ & $2 / 1$ \\
\hline $\mathrm{C} 15$ & Positive & Cardiopathy & Heart $=670 \mathrm{~g}$, apical aneurysm, ganglionitis & $1 / 1$ & $3 / 2$ \\
\hline $\mathrm{C} 16$ & Positive & Cardiopathy & Heart $=540 \mathrm{~g}$, apical aneurysm & $9 / 7$ & $5 / 4$ \\
\hline $\mathrm{C} 17$ & Positive & Cardiopathy & Heart $=580 \mathrm{~g}$, dilated cardiomyopathy & $2 / 2$ & $2 / 2$ \\
\hline $\mathrm{C} 18$ & Positive & Cardiopathy & $\begin{array}{l}\text { Heart }=565 \mathrm{~g}, \text { apical aneurysm, } \\
\text { dilated cardiomyopathy }\end{array}$ & $2 / 2$ & $2 / 2$ \\
\hline CD1 & Positive & Cardiodigestive & $\begin{array}{c}\text { Heart }=600 \mathrm{~g}, \text { amastigotes nest, megacolon, } \\
\text { megaesophagus }\end{array}$ & $3 / 3$ & $2 / 2$ \\
\hline $\mathrm{CD} 2$ & Positive & Cardiodigestive & $\begin{array}{l}\text { Heart }=560 \mathrm{~g}, \text { apical aneurysm, } \\
\text { ganglionitis (esophagus/colon) }\end{array}$ & $2 / 1$ & $2 / 2$ \\
\hline CD3 & Positive & Cardiodigestive & Heart $=400 \mathrm{~g}$, megaesophagus & $3 / 2$ & $3 / 3$ \\
\hline CD4 & Positive & Cardiodigestive & Cardiopathy, megaesophagus & $2 / 2$ & $2 / 2$ \\
\hline CD5 & ND & Cardiodigestive & Heart $=540 \mathrm{~g}$, megacolon, miocarditis & $2 / 2$ & $5 / 5$ \\
\hline
\end{tabular}

ND: not described.

six point standard curve on a logarithmic scale (Fig. 1B). For real-time PCR, we used the Sybr Green Kit, which has a fluorescent probe that intercalates into the DNA molecule and emits a light signal in each cycle.

With the optimum concentration $(150 \mathrm{nM})$ of the TCZ3 and TCZ4 primers and the dilutions of the cloned product, the Ct (Cycle Threshold) vs. sample quantity standard curve was obtained. Amplification efficiency was obtained with the $\mathrm{E}=10^{(-1 / \text { slope })}$ formula, where slope corresponds to the straight-line inclination coefficient (Pfaffl 2001) given by the Gene Amp ${ }^{\circledR}$ SDS (Applied Biosystems) program.

Real-time PCR was performed in $25-\mu \mathrm{L}$ reactions, with $12.5 \mu \mathrm{L}$ of the Sybr Green Mix, $6.25 \mu \mathrm{L}$ of the TCZ1 and TCZ2 $(150 \mathrm{nM})$ primers and $6.25 \mu \mathrm{L}$ the DNA sample mix $(2 n g / \mu \mathrm{L})$. The samples were amplified in a thermocycler ABI Prism 7500 (Applied Biosystems) with the following PCR conditions: first step (2 min at $50^{\circ} \mathrm{C}$ ), second step (denaturation for $10 \mathrm{~min}$ at $95^{\circ} \mathrm{C}$ ) and 40 runs $\left(15 \mathrm{~s}\right.$ at $95^{\circ} \mathrm{C}$ and $1 \mathrm{~min}$ at $\left.60^{\circ} \mathrm{C}\right)$. As an internal reaction control, the human $\beta$-actin gene was amplified in the same amplification cycle for all samples. In each amplification step, a non-template control was subjected to the reaction to ensure that there was no contamination. The results were analyzed with the Gene Amp 7500 Sequence Detector System ${ }^{\circledR}$ Software (Applied Biosystems) showing fluorescence vs. number of cycles.

\section{TABLE II}

Primers for Trypanosoma cruzi nested polymerase chain reaction and real-time polymerase chain reaction

\begin{tabular}{lc}
\hline Primers $^{a}$ & Sequences (5'-3') \\
\hline TCZ1 (forward) & CGAGCTCTTGCCCACACGGGTGCT \\
TCZ2 (reverse) & CCTCCAAGCAGCGGATAGTTCAGG \\
TCZ3 (forward) & TGCTGCASTCGGCTGATCGTTTTCGA \\
TCZ4 (reverse) CARGSTTGTTTGGTGTCCAGTGTTGTGA
\end{tabular}

$a$ : sequences described by Moser et al. (1989) and Ochs et al. (1996) (GenBank acession AY520036). 
Statistical analysis - In the 13 cases when real-time PCR determined the parasitic load in heart tissues, we compared the number of T. cruzi DNA copies and heart weight of each patient using the Spearman Correlation Coefficient. This coefficient varies from -1-1; the values that are close to extremes indicate negative or positive correlation, respectively, and the values close to zero do not indicate correlation (Conover 1980). The software used was SAS System for Windows (Statistical Analysis System, version 9.1.3 Service Pack 3, SAS Institute Inc, 2002-2003, Cary, NC, USA).

A

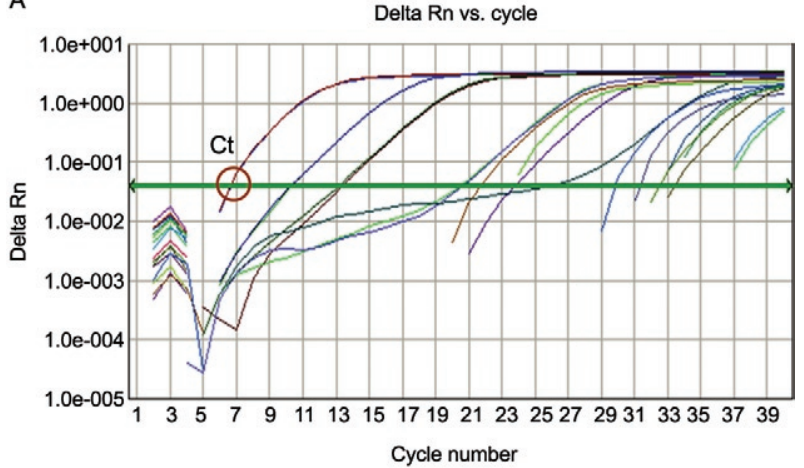

B

Standard curve

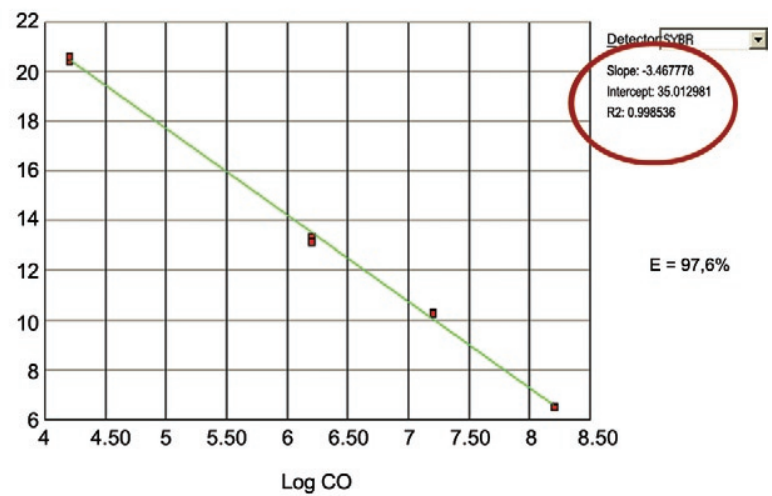

Fig. 1A: quantitative real-time polymerase chain reaction (PCR) of Trypanosoma cruzi DNA in tissues, demonstrating the intercept $(\mathrm{Ct})$ and the DNA samples; B: dynamic range of the T. cruzi satellite DNA based quantitative PCR. Results are expressed in $\log \mathrm{CO}$ (log of number of copies per $2 \mathrm{ng} / \mu \mathrm{L} \mathrm{DNA}$ ).

\section{RESULTS}

We considered as positive samples those that presented the 149-bp amplification product (Fig. 2) obtained from NPCR of the satellite DNA region of T. cru$z i$. From the 18 patients with the cardiac form, a total of 98 samples (56 from heart tissue and 42 from GIT) were randomly analyzed and 83/98 (84.6\%) were positive (48 and 35 from heart and GIT, respectively). Considering the five cases of the cardiodigestive form, 26/28 (92.8\%) samples were positive. In such cases, NPCR was positive for 12/14 (85.7\%) of heart tissue samples and 14/14 $(100 \%)$ of GIT samples as shown in Table III. There was no T. cruzi DNA amplification in any of the negative control samples, showing the specificity of NPCR.

The real-time PCR quantitative method was shown to be reliable and easy to handle. The TCZ3 and TCZ4 primers were standardized at a concentration of $150 \mathrm{nM}$ and $2 \mathrm{ng} / \mu \mathrm{L}$ of DNA were used. Reaction efficiency was $97.6 \%$, calculated by the straight-line inclination coefficient (Pfaffl 2001) with slope $=-3.467778$.

To verify the specificity of the technique when using real-time PCR, every reaction was performed in duplicate and compared to the standard curve, originated from the TCZ3-TCZ4 fragment diluted in logarithmic scale (Fig. 1A, B). The minimum number of copies de-

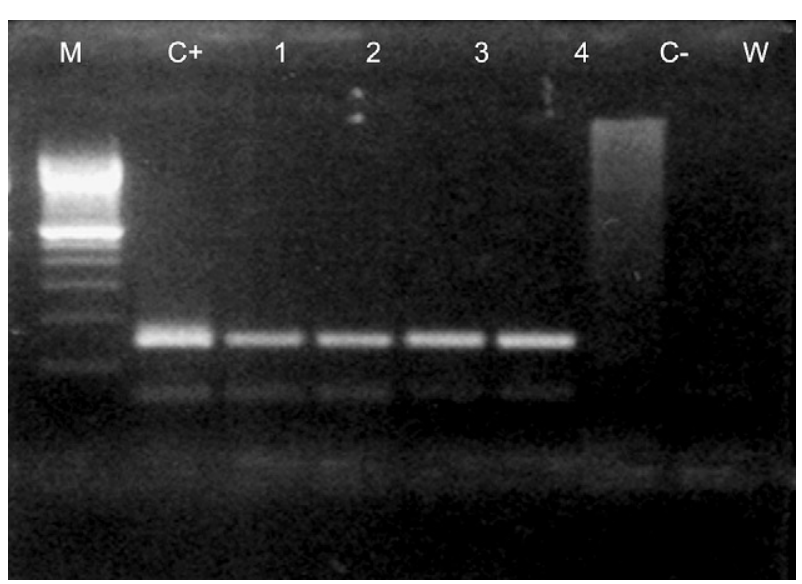

Fig. 2: satellite DNA of Trypanosoma cruzi amplified by nested polymerase chain reaction. C+: Y strain of T. cruzi; C-: negative control; Lanes 1-4: DNA samples of tissues (heart and gastrointestinal tract); M: 100 bp DNA ladder; W: reagents with no DNA.

\section{TABLE III}

Results of nested polymerase chain reaction assay in DNA samples of gastrointestinal tract (GIT) and heart tissues

\begin{tabular}{lcccc}
\hline Clinical form & $\begin{array}{c}\text { Patients } \\
(\mathrm{n})\end{array}$ & $\begin{array}{c}\text { Samples studied } \\
\mathrm{n}(\%)\end{array}$ & $\begin{array}{c}\text { GIT positives } \\
\mathrm{n}(\%)\end{array}$ & $\begin{array}{c}\text { Heart positives } \\
\mathrm{n}(\%)\end{array}$ \\
\hline Cardiac & 18 & $83 / 98(84.6)$ & $35 / 42(83.3)$ & $48 / 56(85.7)$ \\
Cardiodigestive & 5 & $26 / 28(92.8)$ & $14 / 14(100)$ & $12 / 14(85.7)$ \\
Total & 23 & $109 / 126(86.5)$ & $49 / 56(87.5)$ & $60 / 70(85.7)$ \\
Negative controls & 10 & $0 / 20(0)$ & $0 / 10(0)$ & $0 / 10(0)$ \\
\hline
\end{tabular}


tected was 3.12 and the maximum was 1965.23 in $2 \mathrm{ng} /$ $\mu \mathrm{L}$ of DNA. These data were analyzed by the Gene Amp 7500 Sequence Detector System ${ }^{\circledR}$ Software (Applied Biosystems) program. The human $\beta$-actin gene was amplified in all samples in the same reaction runs to assure the quality of tested samples.

\section{TABLE IV}

Number of copies found in cardiac and cardiodigestive forms in Chagas disease by quantitative polymerase chain reaction (QPCR)

\begin{tabular}{lcc}
\hline Samples & $\begin{array}{c}\text { Copies } \\
\text { (n) }\end{array}$ & Clinical form \\
\hline CD1- intestine & 14.15 & Cardiodigestive \\
CD1- sinus node & 33.44 & \\
CD2- GIT, no described & 8.77 & Cardiodigestive \\
CD2- right atrium, left ventricule & 11.54 & \\
C1- esophagus & 5.74 & Cardiac \\
C1- heart, apex & 256.23 & \\
C2- colon & 29.2 & Cardiac \\
C2- ventricule & 283.31 & \\
C3- esophagus & 211.22 & Cardiac \\
C3- left ventriculum, apex & 681.69 & \\
C4- colon & 12.93 & Cardiac \\
C4- left ventricule & 395.87 & \\
C5- large intestine & 4.75 & Cardiac \\
C5- left ventricule & 1770.2 & \\
C6- GIT, no descibed & 35.45 & Cardiac \\
C6- heart, no described & 548.1 & \\
\hline
\end{tabular}

results of quantification by QPCR in eight cases comparing number of copies between heart and gastrointestinal tract (GIT).
In eight samples assessed by real-time PCR, we compared the number of copies of $T$. cruzi DNA by QPCR between the heart and GIT and found that in cases with cardiopathy, the number of copies in the heart was higher (3.2-292 times). In the two patients with the cardiodigestive form the difference between the number of copies was lower (1.3 and 2.3 times) (Table IV).

DNA extracted from the 13 heart samples showed there was no statistical correlation between the heart weight and the number of copies found in this organ or with other pathological data (Fig. 3, Table V). Despite the low number of cases, these data suggest that parasitic loads in the affected tissues are not related to organ damage.

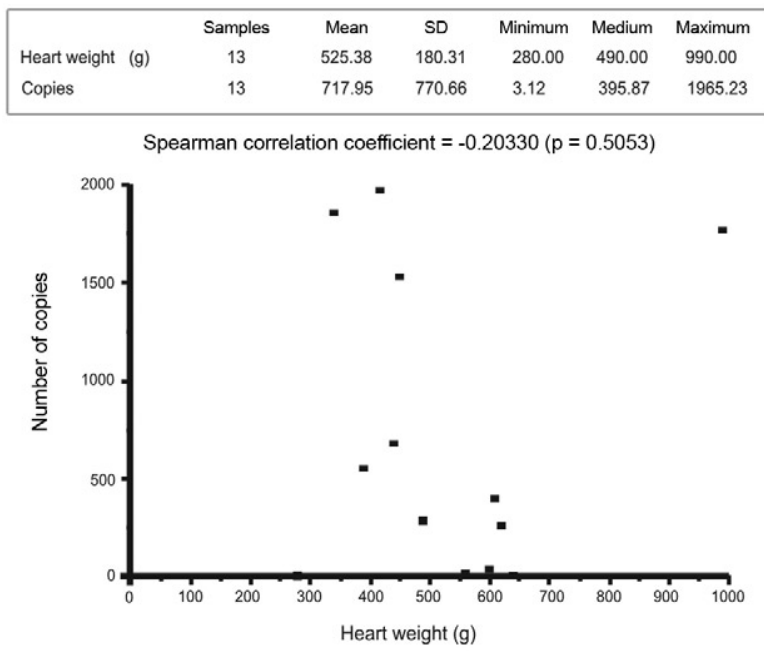

Fig. 3: statistical analysis. Comparison between heart weight and number of copies found by real-time polymerase chain reaction. SD: standard deviation.

TABLE V

Comparison between number of copies found by quantitative polymerase chain reaction and pathological data

\begin{tabular}{|c|c|c|}
\hline Heart samples & Anatomopathological evidences & $\begin{array}{l}\text { Copies } \\
\text { (n) }\end{array}$ \\
\hline C5 - left ventricule & Heart $=990 \mathrm{~g}$, apical aneurysm, amastigotes nest & 1770.2 \\
\hline C7 - left ventricule & Heart $=640 \mathrm{~g}$ & 5.77 \\
\hline C1 - apical tissue & Heart $=620 \mathrm{~g}$, myocarditis, myositis & 256.23 \\
\hline C4 - left ventricule & Heart $=610 \mathrm{~g}$, rosary-bead type epicarditis & 395.87 \\
\hline CD1 - sinus node & Heart $=600 \mathrm{~g}$, amastigotes nest, megacolon, megaesophagus & 33.44 \\
\hline $\mathrm{CD} 2$ - right atrium, left ventricule & Heart $=560 \mathrm{~g}$, ganglionitis (esophagus and colon), apical aneurysm & 11.54 \\
\hline $\mathrm{C} 2$ - ventricule & Heart $=490 \mathrm{~g}$ & 283.31 \\
\hline $\mathrm{C} 8$ - right atrium & Heart $=450 \mathrm{~g}$, myocarditis & 1524.05 \\
\hline C3 - left ventricule, apical tissue & Heart $=440 \mathrm{~g}$ & 681.69 \\
\hline C9 - right atrium & Heart $=420 \mathrm{~g}$ & 1965.23 \\
\hline C6 - no described & Heart $=390 \mathrm{~g}$, dilated cardiomyopathy & 548.1 \\
\hline C10 - no described & Heart $=340 \mathrm{~g}$, apical aneurysm & 1854.84 \\
\hline CD 3 - bundle of Hiss & Heart $=280 \mathrm{~g}$, cardiomyopathy, megaesophagus & 3.12 \\
\hline
\end{tabular}

$\mathrm{CD} 1, \mathrm{CD} 2$ : heart samples (cardiodigestive form), heart weight in decreasing order. Evaluation of number of copies in 13 heart samples and comparison with heart weight; C1-C11: heart samples (cardiac form). 


\section{DISCUSSION}

Through NPCR, Ochs et al. (1996) suggested that $T$. cruzi was present in the heart tissues of children who died of acute Chagas disease. Significant positive association between parasite persistence in heart tissue and myocarditis was demonstrated by PCR in endomyocardial biopsies (Benvenuti et al. 2008). Knowledge of the exact role of the parasite in the pathogenesis of Chagas disease appears extremely important to guide therapeutic strategies (Higuchi et al. 2003).

The aim of this study was to detect and to quantify T. cruzi DNA in tissues of chronic chagasic patients. The DNA detection of parasites through NPCR in tissues corroborates previous findings of Cummings and Tarleton (2003), showing that T. cruzi is present in target organs and may lead to organ damage according to the immune response of each individual. The positive rate for heart and GIT tissues by NPCR was approximately $87 \%$, confirming the high sensitivity of the technique, even in biological samples obtained from paraffin embedded-tissue sections where the fixation techniques lead to DNA loss and folding (Mesquita et al. 2001).

According to the literature, parasites are rarely found in tissues examined by routine staining techniques. However, the utilization of highly sensitive molecular biology tools, such as PCR, has revealed the presence of T. cruzi in involved tissues, but rarely in healthy organs of chronic chagasic patients (Ochs et al. 1996, Vago et al. 2000). When analysing oesophageal tissue and blood samples from chronic chagasic patients with megaoesophagus by PCR and blood cultures, Lages-Silva et al. (2001) found that $98 \%$ of the samples were positive for T. cruzi, confirming the importance of the parasite in the host pathological process. In the same study, using PCR and peroxidase and anti-peroxidase, T. cruzi was detected in $76.9 \%$ of the analyzed megaoesophagus tissues. In our investigation, this rate was $87.5 \%$ when GIT fragments were analyzed by NPCR (Table III), which indicates the presence of T. cruzi even when there was no clinical evidence of digestive commitment and only heart involvement.

Using NPCR-based detection of satellite DNA of $T$. cruzi in infected tissues of chagasic patients, the presence of the parasite may be related to the progression of chagasic cardiopathy and/or colonopathy. According to a review article by Tarleton (2003), authors that support the autoimmunity hypotheses in Chagas disease also admit that the persistence of the parasite plays an important role for the progression of the disease, as proven by detection of the parasite DNA, proteins and even of intact parasites in the infected tissues. Zhang and Tarleton (1999) demonstrated that parasite persistence in experimental models has absolute correlation with the severity of the illness. The detection of T. cruzi DNA in tissues by molecular techniques rescues the role of the parasite in Chagas disease, as well as the expression of its genes over the course of infection (Macedo et al. 2004).

When the number of copies obtained by real-time PCR in heart was compared with GIT samples, we observed that in cardiopathy cases, the number of molecules found was proportionally higher in the heart (3.2-292 times), suggesting that the inflammatory process is related to the presence of T. cruzi. In the two cases with the cardiodigestive form, the difference between the numbers of copies found was significantly lower. Considering that the cardiodigestive form of Chagas disease is less frequent than the cardiac form in Brazil, it is difficult to obtain samples from the heart and GIT of a single patient (Vago et al. 2000). There certainly are several host immunologic factors and parasite antigens involved in the pathogenesis of the chagasic infection. Our findings add value to the importance of quantification of T. cruzi DNA by QPCR for the study of Chagas disease and may be compared, after further investigation, to techniques that use inflammatory markers to help understand the relationship between parasite loads and organ damage. According to Cummings and Tarleton (2003), doubts regarding the role of parasites found in tissues need further clarification. In our study, there was no significant statistical relationship between the heart weight and the number of amplified DNA molecules by QPCR (Fig. 3). Such results indicate that $T$. cruzi affects the target organ but the parasite loads are variable. However, a tendency towards an inverse correlation between the number of copies and the weight of the heart was noted, which might have had statistical significance if the number of cases had been higher.

In the current study, the greatest challenge was to standardize the DNA concentration at a $2 \mathrm{ng} / \mu \mathrm{L}$. It is known that the isolation of genetic material from paraffin-embedded tissue sections yields low amounts of DNA, which is frequently fragmented, degraded and folded with proteins. Due to the low DNA concentration, some samples tested by NPCR were not quantified by real-time PCR. As genomic DNA was used, including human and T. cruzi DNA, we took special care to amplify $\beta$-actin gene in the same PCR cycle, imparting quality to the experimental protocol. However, the standardized technique requires less time and it presents a lower contamination risk that the NPCR.

Our data emphasizes that molecular biology tools, such as NPCR and real-time PCR, used to detect and to quantify DNA extracted from fixed tissues may contribute to a better comprehension of the pathogenesis of Chagas disease (Valadares et al. 2008). The difference in the number of copies found in different tissues by realtime PCR indicates that the variability in parasite load is associated with pathological alterations in target organs as well with disease progression.

\section{ACKNOWLEDGEMENTS}

To Sérgio Paulo de Magalhães, from Experimental Surgery and Medicine Center, School of Medical Science, UNICAMP, and to Cristiane de Oliveira, Luísa CB Keiralla and André FG Larrubia, for their assistance regarding the techniques performed.

\section{REFERENCES}

Adad SJ, Andrade DCS, Lopes ER, Chapadeiro E 1991. Contribuição ao estudo da anatomia patológica do megaesôfago chagásico. Rev Inst Med Trop Sao Paulo 33: 443-450. 
Benvenuti LA, Roggério A, Freitas HF, Mansur AJ, Fiorelli A, Higuchi ML 2008. Chronic American trypanosomiasis: parasite persistence in endomyocardial biopsies is associated with highgrade myocarditis. Ann Trop Med Parasitol 102: 481-487.

Conover WJ 1980. Practical nonparametric statistics, 2nd ed., John Wiley \& Sons, New York, 592 pp.

Cummings KL, Tarleton RL 2003. Rapid quantitation of Trypanosoma cruzi in host tissue by real-time PCR. Mol Biochem Parasitol 129: 53-59.

Duffy T, Bisio M, Altcheh J, Burgos JM, Diez M, Levin MJ, Favaloro RR, Freilij H, Schijman AG 2009. Accurate real-time PCR strategy for monitoring bloodstream parasitic loads in Chagas disease patients. PLoS Negl Trop Dis 3: e419.

Elias MC, Vargas NS, Zingales B, Schenkman S 2003. Organization of satellite DNA in the genome of Trypanosoma cruzi. Mol Biochem Parasitol 129: 1-9.

Freitas JM, Lages-Silva E, Crema E, Pena SD, Macedo AM 2005. Real time PCR strategy for the identification of major lineages of Trypanosoma cruzi directly in chronically infected human tissues. Int J Parasitol 35: 411-417.

Higuchi M de L, Benvenuti LA, Martins Reis M, Metzger M 2003. Pathophysiology of the heart in Chagas' disease: current status and new developments. Cardiovasc Res 60: 96-107.

Jones EM, Colley DG, Tostes S, Lopes ER, Vnencak-Jones CL, McCurley TL 1993. Amplification of a Trypanosoma cruzi DNA sequence from inflammatory lesions in human chagasic cardiomyopathy. Am J Trop Med Hyg 48: 348-357.

Köberle F 1968. Chagas disease and Chagas syndromes: the pathology of American trypanosomiasis. Adv Parasitol 6: 63-116.

Köberle F, Alcântara FG, Ribeiro dos Santos R 1983. Patogenia da forma digestiva. In AA Raia, Manifestações digestivas da moléstia de Chagas, Sarvier, São Paulo, p. 25-34.

Lages-Silva E, Crema E, Ramirez LE, Macedo AM, Pena SD, Chiari E 2001. Relationship between Trypanosoma cruzi and human chagasic megaesophagus: blood and tissue parasitism. Am J Trop Med Hyg 65: 435-441.

Lane JE, Ribeiro-Rodrigues R, Olivares-Villagómez D, VnencakJones CL, McCurley TL, Carter CE 2003. Detection of Trypanosoma cruzi DNA within murine cardiac tissue sections by in situ polymerase chain reaction. Mem Inst Oswaldo Cruz 98: 373-376.

Macedo AM, Machado CR, Oliveira RP, Pena SDJ 2004. Trypanosoma cruzi: genetic structure of populations and relevance of genetic variability to the pathogenesis of Chagas disease. Mem Inst Oswaldo Cruz 99: 1-12.

Macedo AM, Oliveira RP, Pena SD 2002. Chagas disease: role of parasite genetic variation in pathogenesis. Expert Rev Mol Med 4: 1-16.

Marcon GE, Andrade PD, de Albuquerque DM, Wanderley J da S, de Almeida EA, Guariento ME, Costa SC 2002. Use of a nested polymerase chain reaction (N-PCR) to detect Trypanosoma cruzi in blood samples from chronic chagasic patients and patients with doubtful serologies. Diagn Microbiol Infect Dis 43: 39-43.

Mesquita RA, Anzai EK, Oliveira RN, Nunes FD 2001. Avaliação de três métodos de extração de DNA de material parafinado para a amplificação de DNA genômico pela técnica de PCR. Pesqui Odontol Bras 15: 314-319.
Moser DR, Kirchhoff LV, Donelson JE 1989. Detection of Trypanosoma cruzi by DNA amplification using the polymerase chain reaction. J Clin Microbiol 27: 1477-1482.

Ochs DE, Hnilica VS, Moser DR, Smith JH, Kirchhoff LV 1996. Postmortem diagnosis of autochthonous acute chagasic myocarditis by polymerase chain reaction amplification of a species-specific DNA sequence of Trypanosoma cruzi. Am J Trop Med Hyg 54: 526-529.

Pfaffl MW 2001. A new mathematical model for relative quantification in real-time RT-PCR. Nucleic Acids Res 29: 2002-2007.

Piron M, Fisa R, Casamitjana N, López-Chejade P, Puig L, Vergés M, Gascón J, Gómez i Prat J, Portús M, Sauleda S 2007. Development of a real-time PCR assay for Trypanosoma cruzi detection in blood samples. Acta Trop 103: 195-200.

Saiki RK, Scharf S, Faloona F, Mullis KB, Horn GT, Erlich HA, Arnheim N 1985. Enzymatic amplification of beta-globin genomic sequences and restriction site analysis for diagnosis of sickle cell anemia. Science 230: 1350-1354.

Soares MBP, Ribeiro dos Santos R 1999. Immunopathology of cardiomyopathy in the experimental Chagas disease. Mem Inst Oswaldo Cruz 94 (Suppl. I): 257-262.

Tarleton RL 2001. Parasite persistence in the aetiology of Chagas disease. Int J Parasitol 31: 550-554.

Tarleton RL 2003. Chagas disease: a role for autoimmunity? Trends Parasitol 19: 447-451.

Vago AR, Andrade LO, Leite AA, d'Ávila Reis D, Macedo AM, Adad SJ, Tostes S Jr, Moreira MC, Filho GB, Pena SD 2000. Genetic characterization of Trypanosoma cruzi directly from tissues of patients with chronic Chagas disease: differential distribution of genetic types into diverse organs. Am J Pathol 156: 1805-1809.

Vago AR, Macedo AM, Adad SJ, Reis DD, Corrêa-Oliveira R 1996. PCR detection of Trypanosoma cruzi DNA in oesophageal tissues of patients with chronic digestive Chagas disease. Lancet 348: 891-892.

Vago AR, Silva DM, Adad SJ, Correa-Oliveira R, d'Avila Reis D 2003. Chronic Chagas disease: presence of parasite DNA in the oesophagus of patients without megaoesophagus. Trans $R$ Soc Trop Med Hyg 97: 308-309.

Valadares HM, Pimenta JR, de Freitas JM, Duffy T, Bartholomeu DC, Oliveira R de P, Chiari E, Moreira M da C, Filho GB, Schijman AG, Franco GR, Machado CR, Pena SD, Macedo AM 2008. Genetic profiling of Trypanosoma cruzi directly in infected tissues using nested PCR of polymorphic microsatellites. Int J Parasitol 38: 839-850.

Virreira M, Martinez S, Alonso-Vega C, Torrico F, Solano M, Torrico MC, Parrado R, Truyens C, Carlier Y, Svoboda M 2006. Amniotic fluid is not useful for diagnosis of congenital Trypanosoma cruzi infection. Am J Trop Med Hyg 75: 1082-1084.

WHO - World Health Organization 2002. WHO's Certified (database on the Internet). Control of Chagas disease (cited 2010 Jun 20). Available from: http://whqlibdoc.who.int/trs/WHO_ TRS_905.pdf.

Zhang L, Tarleton RL 1999. Parasite persistence correlates with disease severity and localization in chronic Chagas disease. J Infect Dis 180: 480-486. 